\title{
KONDISI KUALITAS AIR WADUK JATIBARANG DITINJAU DARI ASPEK SAPROBITAS PERAIRAN
}

Condition of the Waters Quality of Jatibarang Reservoir based on Water Saprobic Index

\author{
Renita Susanti, Sutrisno Anggoro*), Djoko Suprapto
}

Program Studi Manajemen Sumberdaya Perairan

Departemen Sumberdaya Akuatik, Fakultas Perikanan dan Ilmu Kelautan Universitas Diponegoro

J1. Prof. H. Soedarto, SH. Tembalang, Semarang, Jawa Tengah (renitasusanti82@yahoo.co.id)

\begin{abstract}
Abstrak
Pencemaran air adalah masuknya atau dimasukkannya suatu zat, energi kedalam air oleh kegiatan manusia sehingga kualitas air dapat menurun sampai tingkat tertentu yang mengakibatkan air tidak dapat berfungsi sesuai dengan peruntukannya. Waduk Jatibarang merupakan bendungan yang menampung beberapa aliran sungai yang kemudian menjadi sarana dan prasarana akuatik dan mendukung kegiatan pariwisata yang ada. Masuknya air dari beberapa sungai ke dalam waduk dapat membawa bahan pencemar sehingga dapat mengakibatkan perairan waduk menjadi tercemar. Salah satu indikator penting dalam penentuan kualitas air adalah dengan melihat tingkat saprobitas di perairan. Berdasarkan hal tersebut maka perlu dikaji lebih lanjut mengenai kondisi kualitas perairan Waduk Jatibarang ditinjau dari aspek saprobitas. Tujuan dari penelitian ini adalah untuk mengetahui tingkat saprobitas perairan Waduk Jatibarang. Penelitian ini dilaksanakan pada bulan Mei - Juni 2017. Penelitian ini menggunakan metode studi kasus dengan analisis deskriptif dan analisis korelasi, dengan mengukur parameter pendukung yaitu parameter fisika, kimia, indeks biologi, dan indeks saprobitas. Hasil pengamatan menunjukkan bahwa nilai kelimpahan fitoplankton berkisar antara 236-865 ind/l, indeks keanekaragaman berkisar antara 1.02-1.77 indeks keseragaman berkisar antara 0.58-0.85 dan indeks dominasi berkisar antara 0.14-0.96. Indeks Kualitas Air (IKA) yang didapatkan berkisar antara 51.74-55.06 sehingga kualitas perairan dalam kategori sedang. Berdasarkan hasil penelitian didapatkan bahwa nilai indeks saprobitas berkisar antara 0.60-2.75 dan nilai indeks tropik saprobik berkisar antara 2.02-4.06 sehingga dapat disimpulkan bahwa perairan Waduk Jatibarang termasuk dalam golongan $\beta$-mesosaprobik/ oligosaprobik atau tercemar ringan.
\end{abstract}

Kata Kunci: Indeks Saprobik, Indeks Tropik Saprobik, Plankton, Indeks Kualitas Air, Waduk Jatibarang

\begin{abstract}
Water pollution is entry or inclusion by a substance, energy into water by the human activities so that quality of the water can decrease till the certain level which it can cause the water can be not function in accordance with the designation. Jatibarang Reservoir is a dam that holds several streams from the river which then becomes the aquatic facilities and infrastructure and can support the tourism activities. The entry of the water to reservoir, can carry pollutants it can cause the reservoir be polluted. One of the important indicators to determine the quality of the water is the saprobic level in the water. Based on the matter, it is necessary to study further about condition of the water quality of Jatibarang Reservoir in terms of saprobic aspect. The objective of the research has to know the level of waters saprobic in Jatibarang Reservoir. The research was conducted in May - June 2017. This research used case study method with descriptive analysis and correlation analysis, with measuring the supporting parameters like physics, chemistry, biology index, and saprobic index. The result of the observation showed that the phytoplankton abundance value ranged between 236-865 ind/l, index of diversity ranged between 1.02-1.77, uniformity index ranged between 0.49-0.85, and the index of dominance range between 0.14-0.96. Water Quality Index (WQI) obtained ranged between 51.74-55.06 so that quality of the water in medium category. The result of the research, found that the Saprobic Index value ranged between 0.60-2.75, and the Tropic Saprobic Index value ranged between 2.02-4.06, so it can be concluded that the Jatibarang Reservoir belongs to the class of $\beta$-mesosaprobic/oligosaprobic or light polluted.
\end{abstract}

Keywords: Saprobic Index, Tropic Saprobic Index, Plankton, Water Quality Index, Jatibarang Reservoir

\section{Pendahuluan}

Waduk Jatibarang merupakan bendungan yang menampung beberapa aliran sungai yang kemudian menjadi sarana prasana kegiatan akuatik dan mendukung kegiatan pariwisata yang ada. Kualitas masukan dari lingkungan luar tersebut dari beberapa sungai dapat menentukan status kualitas air dan pencemaran di Waduk Jatibarang tersebut. Masuknya air dari beberapa sungai kedalam waduk dapat membawa bahan pencemar sehingga mengakibatkan perairan waduk menjadi tercemar. 
Pemanfaatan waduk sebagai kawasan wisata alam harus memperhatikan fungsi utama dari waduk tersebut, khususnya bila dikaitkan dengan pembagian kawasan tidak boleh dilakukan pada kawasan bahaya, tetapi sebagian dimungkinkan pada kawasan suaka khususnya pada wisata hutan dan sebagian besar dilakukan pada kawasan bebas. Pemanfaatan waduk sebagi tempat wisata tidak boleh sampai mengganggu fungsi utama dari waduk tersebut (Sumargo, 2006).

Pencemaran perairan disebabkan oleh banyak faktor namun yang sering terjadi karena buangan limbah rumah tangga, limbah industri, limbah pertanian dan lainnya. Berbagai kegiatan manusia yang berhubungan dengan pemanfaatan sumberdaya alam, pembuangan limbah industri, pertanian dan pertambangan yang tidak terkontrol dapat mengakibatkan terganggunya suatu ekosistem. Perairan Waduk Jatibarang mempunyai masalah pencemaran akibat masuknya air dari beberapa sungai kedalam waduk yang membawa limbah sehingga dapat mengakibatkan perairan waduk tercemar. Atas hal tersebut maka perlu dilakukannya penelitian mengenai kondisi kualitas perariran Waduk Jatibarang ditinjau dari aspek saprobitas perairan. Kelimpahan plankton yang akan digunakan untuk menentukan nilai saprobitas dan nilai tropik saprobik indeks di Waduk Jatibarang.

Penelitian ini bertujuan untuk mengetahui tingkat saprobitas di Waduk Jatibarang Semarang berdasarkan nilai Saprobik Indeks (SI) dan Tropik Saprobik Indeks (TSI). Penelitian ini telah dilakukan pada bulan Mei-Juni 2017 di Waduk Jatibarang, Semarang.

\section{Materi dan Metode Penelitian}

\section{A. Materi Penelitian}

Materi yang digunakan pada penelitian ini adalah sampel air yang didapat di Waduk Jatibarang. Adapun alat-alat yang digunakan meliputi alat untuk sampling lapangan dan identifikasi plankton. Alat yang digunakan pada saat sampling lapangan yaitu plankton net, botol sampel, pipet tetes, termometer, secchi disk, pH paper, roll meter, kertas label, alat tulis dan kamera. Alat yang digunakan untuk identifikasi plankton yaitu mikroskop dan sedgwick-rafter. Bahan yang digunakan dalam penelitian ini adalah reagen untuk pengukuran DO, lugol's iodine untuk pengawetan sampel plankton, sampel plankton, air sampel yang didapat dari Waduk Jatibarang.

\section{B. Metode}

Metode yang digunakan dalam penelitian ini yaitu metode studi kasus dengan analisis deskriptif dan analisis korelasi . Studi kasus adalah studi yang mempelajari objek secara mendalam pada waktu, tempat dan populasi yang terbatas sehingga memberikan informasi tentang situasi dan kondisi secara lokal dan hasilnya tidak berlaku untuk tempat dan waktu yang berbeda.

Metode sampling yang digunakan yaitu metode purposive sampling. Menurut Ferdian et al., (2012), metode purposive sampling yaitu metode yang dilakukan dengan pengambilan sampel berdasarkan keperluan penelitian, artinya teknik pengambilan sampel yang dilakukan secara sengaja dengan pertimbangan tertentu oleh peneliti dengan harapan sampel yang didapat dapat memberikan informasi yang diinginkan sesuai dengan permasalahan peneliti.

Lokasi pengambilan sampel dilakukan di Waduk Jatibarang. Pengambilan sampel air dilakukan di 4 stasiun yaitu inlet, tengah waduk, dibawah jembatan kreo, dan outlet waduk, pengambilan sampel dilakukan pada pagi, siang dan sore hari. Pengambilan air sampel dilakukan pada kawasan Waduk Jatibarang Semarang, dengan empat stasiun yaitu; 1) stasiun satu merupakan daerah inlet terletak pada koordinat $7^{\circ} 2^{\prime}$ ' $45^{\prime \prime}$ LS dan $110^{\circ} 21^{\prime} 30^{\prime \prime}$ BT; 2) stasiun dua terletak pada tengah waduk dengan koordinat $7^{\circ} 2$ ' 30" LS dan $110^{\circ} 20^{\prime} 45^{\prime \prime}$ BT; 3) stasiun tiga terletak dibawah jembatan kreo dengan koordinat $7^{\circ} 2$ ' $15^{\prime \prime}$ LS dan $110^{\circ} 21^{\prime}$ 0" BT; dan 4) stasiun empat merupakan daerah outlet dengan koordinat $7^{\circ} 2^{\prime} 0^{\prime \prime} \mathrm{LS}$ dan $110^{\circ} 21^{\prime} 0$ " BT.

\section{Peta Lokasi Sampling}

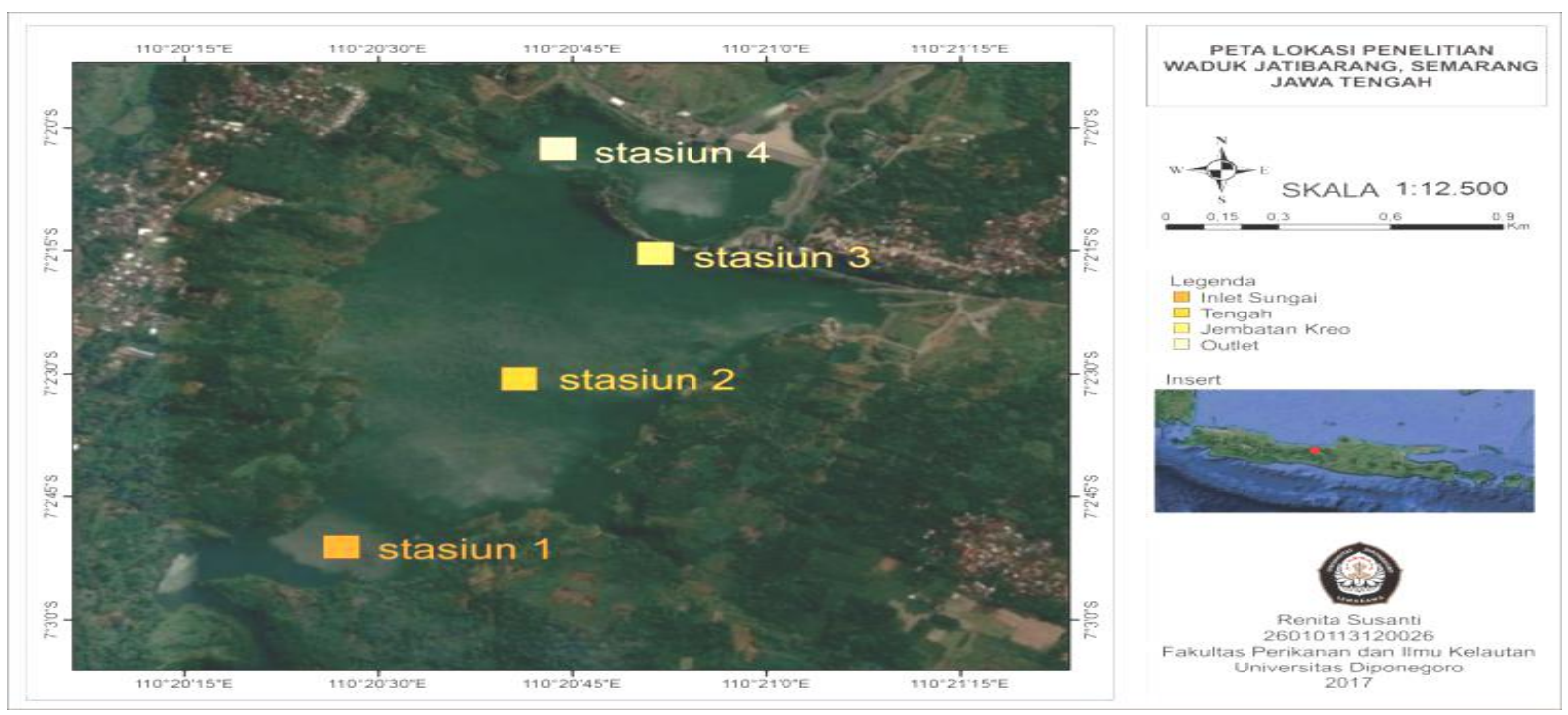

${ }^{\circ}$ Copyright by Management of Aquatic Resources (MAQUARES) 
Gambar 1. Lokasi Stasiun Pengambilan Air Sampel di Waduk Jatibarang

Sumber: Google Earth Digital Globe Data Peta 2017

Analisis Data

Perhitungan nilai indeks kualitas air dengan menggunakan rumus NSF-WQI. Metode yang diusulkan berdasarkan lima parameter kualitas air seperti suhu, $\mathrm{pH}$, oksigen terlarut, biological oxygen demand (BOD), dan nitrat. Data kualitas air tersebut direkam dan di transfer kedalam kurva pembobotan dimana nilai Qi (sub indeks parameter kualitas air diperoleh). Identifikasi organisme plankton dilakukan dengan menggunakan mikroskop binokuler. Pengamatan dan perhitungan organisme dilakukan dengan bantuan Sedgwick rafter. Identifikasi plankton dengan menggunakan buku identifikasi plankton Sachlan (1982). Setelah dilakukan identifikasi jenisjenis plankton dilakukan perhitungan untuk mencari nilai kelimpahan jenis, indek keanekaragaman, indeks keseragaman, indeks dominasi, saprobik indeks dan tropik saprobik indeks.

\section{Indeks Kualitas Air}

Perhitungan nilai indeks kualitas air dengan menggunakan rumus NSF-WQI (National Sanitation Foundation- Water Quality Index), sebagai beriukut (Tyagi et al., 2013):

\section{Keterangan:}

$\mathrm{WQI}=\sum_{i=1}^{n} Q i W i$

$\mathrm{n}=$ Jumlah parameter yang dihitung

i $=$ Parameter

Qi = Nilai kurva sub indeks parameter kualitas air dengan besaran antara 0-100

$\mathrm{Wi}=$ Unit pembebanan parameter dengan besaran antara $0-1$

Dimana nilai WQI digolongkan menjadi 5 peringkat yaitu:

\begin{tabular}{cc}
\hline Nilai WQI & Kategori Penilaian Kualitas Air \\
\hline $0-25$ & Dalam peringkat sangat buruk \\
$25-50$ & Dalam peringkat buruk \\
$50-70$ & Dalam peringkat sedang \\
$70-90$ & Dalam peringkat baik \\
$90-100$ & Dalam peringkat sangat baik \\
\hline
\end{tabular}

\section{Kelimpahan Fitoplankton}

Perhitungan kelimpahan fitoplankton dilakukan dengan menggunakan metode Sedgwick rafter (Odum, 1971), dengan rumus sebagai berikut:

$$
\mathrm{N}=\frac{\mathrm{ns} \times \mathrm{Va}}{\mathrm{Vs} \times \mathrm{Vc}}
$$

Keterangan:

$\mathrm{N} \quad=\quad$ Jumlah individu per liter air sampel

ns $\quad=$ Jumlah individu plankton pada sedgwick rafter

$\mathrm{Va} \quad=$ Volume sampel fitoplankton yang tersaring dalam botol

Vs $\quad=$ Volume sampel fitoplankton dalam preparat sedgwick rafter $(1 \mathrm{ml})$

$\mathrm{Vc} \quad=\quad$ Volume air sampel yang tersaring

\section{Indeks Keanekaragaman}

Analisis ini digunakan untuk keanekaragaman jenis biota perairan. Persamaan yang digunakan untuk menghitung indeks ini adalah persamaan Shanon-Wiener, sebagai berikut:

$$
\mathrm{H}^{\prime}=-\Sigma \frac{\mathrm{ni}}{\mathrm{N}} \log \frac{\mathrm{ni}}{\mathrm{N}} \quad \begin{aligned}
& \mathrm{H}^{\prime}=\text { Indeks keanekaragaman spesies } \\
& \mathrm{ni}=\text { Jumlah individu spesies ke-i } \\
& \mathrm{N}=\text { Jumlah total individu }
\end{aligned}
$$

Semakin tinggi nilai indek keanekaragaman jenis (H') menunjukkan semakin tinggi kelimpahannya. Nilai indeks berkisar antara 1,5-3,5 dapat ditunjukkan berikut ini, Basmi, (2000):

$H^{\prime}<1$ : Komunitas biota dinyatakan tidak stabil (kualitas air tercemar berat);

H' 1-3 : Stabilitas komunitas dinyatakan moderat (kualitas air tercemar sedang); 
H’> 3 : Stabilitas komunitas biota dinyatakan stabil (kualitas air bersih).

\section{Indeks Keseragaman}

Indeks ini menunjukan pola sebaran biota, yaitu merata atau tidak. Jika nilai indeks keseragaman relatif tinggi maka keberadaan setiap jenis biota di perairan dalam kondisi merata. Analisis indeks keseragaman fitoplankton dan zooplankton menggunakan rumus sebagai berikut (Odum, 1971):

$$
\mathrm{e}=\frac{\mathrm{H}^{\prime}}{\ln \mathrm{S}} \quad \begin{aligned}
& \text { Keterangan: } \\
& \mathrm{e}=\text { Indeks keseragaman } \\
& \mathrm{H}^{\prime}=\text { Indeks keseragaman Shannon } \\
& \mathrm{S}=\text { Jumlah macam spesies penyusun komunitas }
\end{aligned}
$$

\section{Indeks Dominasi}

Indeks dominasi digunakan untuk mengetahui adanya dominasi tertentu di perairan dengan menggunakan persamaan sebagai berikut (Odum, 1971):

Keterangan:

$\mathrm{S}$

$\mathrm{d}=$ Indeks dominansi Simpson

$$
\begin{array}{ll}
\mathrm{d}=\sum_{\mathrm{i}=1}[\mathrm{ni} / \mathrm{N}]^{2} & \mathrm{Ni}=\text { Jumlah individu jenis ke-1 } \\
& \mathrm{N}=\text { Jumlah total individu } \\
& \mathrm{S}=\text { Jumlah jenis }
\end{array}
$$

\section{Saprobik Indeks (SI) dan Tropik Saprobik Indeks (TSI)}

Untuk menghitung saprobitas perairan digunakan analisis TROSAP yang nilainya ditentukan dari hasil formulasi Persone dan De Pauw (1979):

$$
\begin{array}{ll} 
& \text { Keterangan: } \\
& \mathrm{SI}=\text { Saprobik Indeks } \\
\mathrm{SI}=\frac{1 \mathrm{C}+3 \mathrm{D}+1 \mathrm{~B}-3 \mathrm{~A}}{1 \mathrm{~A}+1 \mathrm{~B}+1 \mathrm{C}+1 \mathrm{D}} \quad & \mathrm{B}=\text { Jumlah spesies organisme Polisaprobik } \\
& \mathrm{C}=\text { Jumlah spesies organisme } \alpha \text { - Mesosaprobik } \\
& \mathrm{D}=\text { Jumlah spesies organime Oligosaprobik }
\end{array}
$$

$\mathrm{TSI}=\frac{1(n \mathrm{C})+3(\mathrm{nD})+(\mathrm{nB})-3(\mathrm{nA})}{1(\mathrm{nA})+1(\mathrm{nB})+1(n \mathrm{C})+1(n \mathrm{D})} \times \frac{n \mathrm{~A}+\mathrm{nB}+\mathrm{nC}+\mathrm{nD}+\mathrm{nE}}{\mathrm{nA}+\mathrm{nB}+\mathrm{nC}+\mathrm{nD}}$

$\mathrm{N}$ = jumlah individu organisme pada setiap kelompok saprobitas

$\mathrm{nA}=$ jumlah individu penyusun kelompok polisaprobik

$\mathrm{nB}=$ jumlah individu penyusun kelompok $\alpha$-mesosaprobik

$\mathrm{nC}=$ jumlah individu penyusun kelompok $\beta$-mesosaprobik

$\mathrm{nD}=$ jumlah individu penyusun kelompok oligosaprobik

$\mathrm{nE}=$ jumlah individu penyusun selain $\mathrm{A}, \mathrm{B}, \mathrm{C}$ dan $\mathrm{D}$

\section{Hasil dan Pembahasan}

\section{Gambaran Umum Lokasi Sampling}

Waduk Jatibarang dibangun untuk mengatasi masalah banjir yang sering terjadi di Kota Semarang. Selain untuk menanggulangi masalah banjir waduk tersebut juga dimanfaatkan sebagai obyek wisata. Pada lokasi waduk terdapat ikan-ikan yang sengaja ditebar untuk meningkatan wisata pemancingan yang ada pada lokasi waduk tesebut. Kawasan Waduk Jatibarang ditetapkan sebagai kawasan strategis daya dukung lingkungan hidup, dengan fungsi utama sebagai pengendali limpahan air ke kawasan dibawahnya dan pembangunan wisata.

\section{Indeks Kualitas Air}

Berdasarkan hasil pengukuran Indeks Kualitas Air (IKA) didapatkan hasil sebagai berikut: Tabel 1. Hasil Pengukuran Indeks Kualitas Air di Kawasan Waduk Jatibarang, Semarang.

\begin{tabular}{ccccccc}
\hline \multirow{2}{*}{ No } & \multirow{2}{*}{ Sampling } & Stasiun & \multicolumn{3}{c}{ Waktu } & Pustaka \\
\cline { 3 - 5 } & & 1 & Pagi & Siang & Sore & \\
\hline \multirow{3}{*}{1} & 2 & 54.52 & 51.74 & 52.28 & 51-70 : Kualitas Perairan \\
& 1 Juni 2017 & 3 & 54.52 & 54.59 & 54.46 & dalam kategori sedang \\
& & 4 & 55.06 & 52.10 & 52.46 & (Tyagi et al., 2013) \\
\hline
\end{tabular}




\section{Nilai Indeks Biologi}

Hasil dari pengamatan plankton di empat stasiun pada pagi, siang, dan sore hari didapatkan hasil sebagai berikut:

Tabel 2. Indeks Biologi pada Pagi, Siang, dan Sore Hari di Empat Stasiun

\begin{tabular}{clclcccc}
\hline \multirow{2}{*}{ Waktu } & \multirow{2}{*}{ Stasiun } & \multicolumn{7}{c}{ Indeks Biologi } \\
\cline { 3 - 8 } & 1 & 1.61 & Sedang & 0.77 & Kemerataan Tinggi & 0.27 & Dominasi Rendah \\
& & H' & Kategori(H') & $\mathrm{e}$ & Kategori (e) & $\mathrm{D}$ & Kategori (D) \\
Pagi (07.00 & 2 & 1.29 & Sedang & 0.62 & Kemerataan Tinggi & 0.39 & Dominasi Rendah \\
WIB) & 3 & 1.52 & Sedang & 0.73 & Kemerataan Tinggi & 0.29 & Dominasi Rendah \\
& 4 & 1.52 & Sedang & 0.73 & Kemerataan Tinggi & 0.29 & Dominasi Rendah \\
\hline & 1 & 1.77 & Sedang & 0.85 & Kemerataan Tinggi & 0.46 & Dominasi Rendah \\
Siang (13.00 & 2 & 1.24 & Sedang & 0.60 & Kemerataan Tinggi & 0.14 & Dominasi Rendah \\
WIB) & 3 & 1.58 & Sedang & 0.73 & Kemerataan Tinggi & 0.38 & Dominasi Rendah \\
& 4 & 1.44 & Sedang & 0.69 & Kemerataan Tinggi & 0.23 & Dominasi Rendah \\
\hline Sore (16.00 & 2 & 1.32 & Sedang & 0.64 & Kemerataan Rendah & 0.96 & Dominasi Tinggi \\
WIB) & 3 & 1.30 & Sedang & 0.63 & Kemerataan Tinggi & 0.20 & Dominasi Rendah \\
& 4 & 1.35 & Sedang & 0.65 & Kemerataan Tinggi & 0.27 & Dominasi Rendah \\
& 1 & Sedang & 0.58 & Kemerataan Tinggi & 0.27 & Dominasi Rendah \\
\hline
\end{tabular}

Hasil identifiksi plankton dapat disajikan kedalam diagram batang rata-rata spesies plankton yang mendominasi yaitu spesies Arthrodesmus incus dan spesies plankton yang jarang ditemukan yaitu spesies Euglena viridis yang terdapat di empat stasiun pada pagi, siang dan sore hari (puku 07.00, 13.00 dan 16.00 WIB) dapat dilihat pada Gambar 2 sampai dengan Gambar 4 berikut ini:

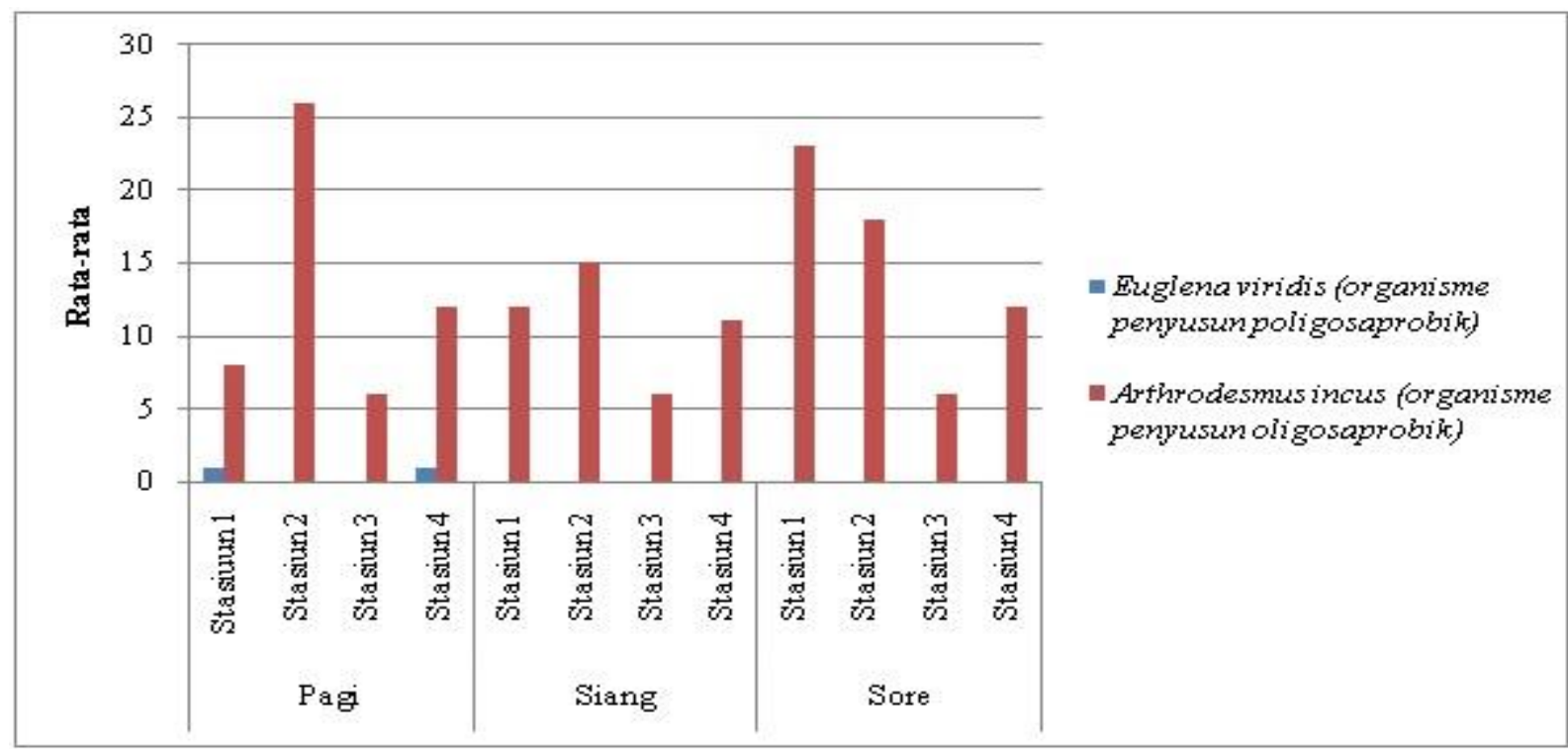

Gambar 2. Rata-rata Spesies Euglena viridis dan Arthrodesmus incus pada Pagi, Siang, dan Sore Hari

Gambar 2 menunjukkan rata-rata spesies plankton yang mendominasi dan yang jarang ditemukan padi empat stasiun dengan selang waktu yang berbeda yaitu pada pagi hari (pukul 07.00), pada siang hari (pukul 13.00) dan pada sore hari (pukul 16.00). Spesies yang mendominasi di perairan Waduk Jatibarang adalah spesies Arthrodesmus incus. Rata-rata spesies plankton pada pagi hari yang didapatkan yaitu 26 ind/l. Rata-rata spesies plankton pada siang hari yang didapatkan yaitu plankton 15 ind/l, dan rata-rata spesies plankton pada sore hari yang didapatkan yaitu 18 ind/l. Spesies yang jarang ditemukan di perairan Waduk Jatibarang adalah spesies Euglena viridis. Pada siang dan sore hari tidak ditemukan spesies Euglena viridis. 


\section{Indeks Saprobitas dan Indeks Tropik Saprobik}

Hasil perhitungan dan kategori indeks saprobitas perairan Waduk Jatibarang di empat stasiun pada pagi, siang dan sore hari adalah sebagai berikut:

Tabel 3. Nilai SI dan Kategori di Stasiun 1, 2, 3 dan 4 pada Pagi, Siang dan Sore Hari

\begin{tabular}{llll}
\hline Waktu & Stasiun & SI & Kategori \\
\hline \multirow{3}{*}{ Pagi (07.00 WIB) } & 1 & 0,60 & $\beta$-mesosaprobik \\
& 2 & 2,75 & Oligosaprobik \\
& 3 & 2,20 & Oligosaprobik \\
& 4 & 0,60 & $\beta$-mesosaprobik \\
Siang (13.00 WIB) & 1 & 1,66 & Oligosaprobik \\
& 3 & 1,66 & Oligosaprobik \\
& 4 & 2,00 & Oligosaprobik \\
Sore (16.00 WIB) & 1 & 1,80 & Oligosaprobik \\
& 2 & 2,00 & Oligosaprobik \\
& 3 & 2,00 & Oligosaprobik \\
& 4 & 2,30 & Oligosaprobik \\
\hline
\end{tabular}

Hasil perhitungan dan kategori indeks tropik saprobik perairan Waduk Jatibarang di empat stasiun pada pagi, siang dan sore hari adalah sebagai berikut:

Tabel 4. Nilai TSI dan Kategori di Stasiun 1, 2, 3, dan 4 pada Pagi, Siang dan Sore

\begin{tabular}{llll}
\hline Waktu & Stasiun & TSI & Kategori \\
\hline \multirow{3}{*}{ Pagi } & 1 & 3,16 & Oligosaprobik \\
& 2 & 4,06 & Oligosaprobik \\
& 3 & 3,64 & Oligosaprobik \\
& 4 & 3,29 & Oligosaprobik \\
\multirow{3}{*}{ Siang } & 1 & 3,24 & Oligosaprobik \\
& 2 & 3,47 & Oligosaprobik \\
& 3 & 2,02 & Oligosaprobik \\
\multirow{3}{*}{ Sore } & 4 & 3,42 & Oligosaprobik \\
& 1 & 3,37 & Oligosaprobik \\
& 2 & 3,38 & Oligosaprobik \\
& 3 & 3,76 & Oligosaprobik \\
\hline
\end{tabular}

\section{Pembahasan \\ Indeks Kualitas Air}

Parameter kualitas air yang diukur pada penelitian ini adalah parameter fisika dan kimia. Suhu air pada pagi hari di empat stasiun berkisar antara $27^{\circ} \mathrm{C}-29^{\circ} \mathrm{C}$, pada siang hari suhu air pada keempat stasiun berkisar antara $29^{\circ} \mathrm{C}-31^{\circ} \mathrm{C}$, dan pada sore hari suhu air berkisar antara $26,5^{\circ} \mathrm{C}-27^{\circ} \mathrm{C}$. Nilai suhu air yang bervariasi dapat dipengaruhi oleh beberapa faktor seperti cuaca, angin dan arus. Menurut Effendi (2003), suhu suatu badan air dipengaruhi oleh musim, lintang (latitude), ketinggian dari permukaan laut (atitude), waktu dalam hari, sirkulasi udara penutupan awan, dan aliran serta kedalaman suatu perairan.

Nilai kadar oksigen terlarut pada perairan Waduk Jatibarang yaitu berkisar antara $6.5-8.0 \mathrm{mg} / \mathrm{l}$, nilai tersebut dapat dipengaruhi oleh kepadatan fitoplankton serta cuaca pada saat pengukuran. Nilai oksigen terlarut tersebut masih tergolong baik untuk kehidupan organisme perairan. Menurut PP Nomor 82 Tahun 2001 baku mutu kadar DO kelas dua adalah $4 \mathrm{mg} / \mathrm{l}$. Oksigen terlarut dimanfaatkan oleh biota perairan untuk proses respirasi, dan menguraikan zat organik menjadi anorganik oleh mikroorganisme. Menurut Happy et al., (2012) penurunan kadar oksigen terlarut diperairan merupakan indikasi adanya pencemaran. Nilai oksigen terlarut yang rendah disebabkan banyaknya limbah yang masuk kedalam perairan.

Kandungan nitrat pada perairan Waduk Jatibarang, Semarang berkisar antara 0,5-1,4 mg/l. Kandungan nitrat tertinggi terdapat di stasiun 1 pada pagi hari. Stasiun 1 merupakan inlet dari Waduk Jatibarang, nilai nitrat 
pada pagi hari di stasiun 1 mencapai $1,4 \mathrm{mg} / \mathrm{l}$ dapat disebabkan oleh masuknya limbah yang mengandung senyawa organik dan senyawa anorganik yang terbawa oleh aliran sungai menuju waduk. Menurut Effendi (2003), kadar nitrat nitrogen yang lebih dari $0,2 \mathrm{mg} / \mathrm{l}$ dapat mengakibatkan terjadinya eutrofikasi perairan, yang selanjutnya mengakibatkan blooming algae dan tumbuhan perairan secara pesat.

Nilai hasil pengukuran $\mathrm{pH}$ pada Waduk Jatibarang stabil pada nilai $\mathrm{pH} 8$ yang menunjukkan perairan memiliki $\mathrm{pH}$ basa. Nilai $\mathrm{pH}$ yang didapatkan dari hasil pengamatan pada setiap stasiun cukup baik untuk kehidupan biota perairan. Nilai ini masih memenuhi baku mutu. Berdasarkan PP No. 82 Tahun 2001 baku mutu nilai $\mathrm{pH}$ pada perairan kelas dua yaitu berkisar 6-9. Menurut Syamiazi et al., (2015) nilai pH sangat mempengaruhi proses biokimiawi perairan, misalnya proses nitrifikasi akan berakhir pada pH kurang dari 6 . Nilai pH yang tinggi pada lapisan permukaan perairan menandakan adanya indikasi hypereutrifik, nilai pH yang tinggi dengan kisaran $\mathrm{pH}$ dapat mencapai 10 menggambarkan tingginya pertumbuhan alga.

Hasil analisis terhadap nilai BOD pada empat stasiun pagi, siang dan sore berkisar antara 1,5 - 2,7 mg/l. Nilai kadar BOD pada Waduk Jatibarang masih berada pada kisaran normal dan baik untuk pertumbuhan organisme didalamnnya. Berdasarkan PP No. 82 Tahun 2001 baku mutu kandungan BOD pada perairan kelas dua, kurang dari $3 \mathrm{mg} / \mathrm{l}$. Nilai BOD tersebut mengindikasikan bahwa perairan Waduk Jatibarang belum adanya cemaran organik dan telah memenuhi kebutuhan oksigen bagi organisme perairan.

Hasil analisis kandungan COD pagi, siang dan sore didapatkan hasil pada stasiun 1 nilai COD berkisar antar 20,39 - 23,08 mg/l, pada stasiun 2 nilai COD berkisar antara 18,31 - 19,15 mg/l, nilai COD pada stasiun 3 berkisar antara 14,98 - 19,33 mg/l, dan pada stasiun 4 nilai COD berkisar antara 14,91 - 19,56 mg/l. Hasil pengukuran yang dilakukan pada keempat stasiun di Waduk Jatibarang menunjukkan adanya variasi nilai COD. Berdasarkan PP No 82 Tahun 2001 baku mutu kandungan COD pada perairan kelas dua adalah $25 \mathrm{mg} / \mathrm{l}$. Sehingga dapat dikatakan bahwa kandungan COD pada perairan Waduk Jatibarang masih tergolongan normal dan tidak melebihi baku mutu.

Hasil Indeks Kualitas Air (IKA) pada stasiun 1 yaitu berkisar antara 51.74 - 52.28 yang menunjukkan kualitas perairan dalam kategori sedang. Stasiun 2 pada pagi, siang dan sore hari didapatkan hasil Indeks Kualitas Air (IKA) berkisar antara 54.46-54.59 termasuk kualitas perairan dalam kategori sedang. Stasiun 3 pada pagi, siang dan sore hari didapatkan hasil Indeks Kualitas Air (IKA) berkisar antara 52.10 - 55.06 termasuk kualitas perairan dalam kategori sedang, dan pada stasiun 4 yang dilakukan pengukuran pada pagi, siang dan sore hari didapatkan hasil Indeks Kualitas Air (IKA) berkisar antara 52.10 - 52.16 termasuk kualitas perairan dalam kategori sedang. Menurut Tyagi et al., (2013), kualitas perairan dikatakan buruk apabila nilai Indeks Kualitas Air (IKA) yang didapatkan berkisar antara 26-50, dan kualitas perairan sedang apabila nilai Indeks Kualitas Air (IKA) yang didapatkan berkisar antara 51-70.

\section{Indeks Biologi}

Hasil identifikasi dan perhitung fitoplankton yang didapatkan pada saat penelitian ditemukan 11 spesies dan yang paling mendominasi adalah spesies Arthrodesmus sp. Hasil yang didapatkan dari analisis indeks keanekaragaman fitoplankton ( $\left.\mathrm{H}^{\prime}\right)$ di Waduk Jatibarang berkisar antara 1.20-1.77. Keanekaragaman pada perairan Waduk Jatibarang tergolong sedang. Menurut Pirzan dan Petrus (2008), semakin besar nilai keanekaragaman (H') hal ini menunjukkan semakin beragamnya kehidupan diperairan tersebut, kondisi ini merupakan tempat hidup yang lebih baik. Kriteria nilai keanekaragaman adalah $\mathrm{H}^{\prime}<1$, maka komunitas biota dinyatakan tidak stabil atau kualitas air tercemar berat, $1<\mathrm{H}^{\prime}<3$, maka stabilitas komunitas sedang atau kualitas air tercemar sedang, $\mathrm{H}^{\prime}>3$, stabilitas komunitas biota dalam kondisi stabil atau kualitas perairan bersih.

Hasil analisis indeks keseragaman (e) fitoplankton di Waduk Jatibarang berkisar antara 0.58-0.85. Tingkat keseragaman pada perairan Waduk Jatibarang tergolong tinggi. Hasil analisis indeks dominasi (D) fitoplankton di Waduk Jatibarang berkisar antara 0.14-0.96. Indeks dominasi pada perairan Waduk Jatibarang tergolong rendah, namun di stasiun I pada sore hari indeks dominasi tinggi yaitu 0.96 .

Kelimpahan fitoplankton di Waduk Jatibarang berkisar antara 236-865 ind/l. Tingginya jumlah dan kelimpahan spesies fitoplankton dipengaruhi dengan kondisi lingkungan perairan, adanya ketahanan daya adaptasi fitoplankton terhadap pencemaran sehingga berpengaruh terhadap rendahnya jumlah kelimpahan yang ditemukan.

\section{Hasil Analisis Saprobik dan Tropik Saprobik}

Berdasarkan nilai SI dan TSI dapat diketahui bahwa kondisi perairan di Waduk Jatibarang Semarang termasuk kategori tercemar ringan. Nilai SI pada pagi hari berkisar antara 0.60-2.75, pada siang hari berkisar antara 1.66-2.00, sedangkan pada sore hari berkisar antara 2.00-2.30. Berdaarkan hasil pengamatan kisaran nilai tersebut termasuk dalam golongan $\beta$-mesosaprobik/oligosaprobik atau tercemar ringan. Nilai tersebut ditandai adanya spesies Chilomonas paramecium, Rhizosolenia alata, Nauplius sp, Scenedesmus obliquus, Pediastrum simplex, Arthrodesmus incus, Synedra acus, dan Euglena viridis. Menurut Wartiniyati et al., (2010) indeks saprobitas dengan rentan nilai 1.14-3.00 termasuk dalam kategori tercemar ringan ditandai dengan adanta jasad 
renik seperti Skeleton spesie Synedra acus, Nithchia palaea, Rapidium polimorphum, Oscillatoria formosa, Schroederia setigera, dan Diatom vulgare. Nilai Saprobic Index terendah yaitu pada stasiun 1 dan 4 dengan nilai 0.66 yang termasuk dalam golongan $\beta$-mesosaprobik, pada stasiun 1 dan 4 terdapat spesies Euglena viridis, namun jumlahnya tidak banyak. Euglena viridis merupakan organisme penyusun saprobitas golongan polisaprobik atau tercemar berat. Menurut Kasrina et al., (2012), Euglena sp memiliki dua buah flagel tipe cambuk berjumbai, dengan tonjolan lateral yang berupa bulu yang terletak pada satu baris panjang flagel. Euglena sp dapat hidup secara autrotof maupun heterotrof pada saat sinar matahari mencukupi spesies ini melakukan fotosintesis tetapi bila tidak terdapat matahari Euglena sp mengambil zat organik yang terlarut di sekitarnya. Variabel kualitas air yang mempengaruhi besar kecilnya nilai indeks saprobitas antara lain oksigen terlarut, BOD, dan COD.

Hasil dari analisis indeks tropik saprobik di empat stasiun pada pagi hari berkisar antara 3.16-4.06. Nilai TSI pada siang hari di empat stasiun berkisar antara 2.02-3.47, dan pada sore hari nilai TSI berkisar antara 2.93-3.78. Hasil yang didapatkan menunjukkan bahwa tinggkat pencemaran yang terjadi pada perairan Waduk Jatibarang tergolong oligosaprobik. Terdapat perbedaan nilai TSI pada pagi, siang, dan sore hari. Perbedaan nilai tersebut dapat dipengaruhi oleh sifat fisika, kimia dan biologis suatu perairan. Berdasarkan hasil tersebut didasarkan pada sifat distribusi plankton disuatu perairan. Menurut Haryati et al., (2010), kelompok fitoplankton yang ada pada perairan golongan oligosaprobik umumnya mendiami perairan yang tidak tercemar. Bahan yang mencemari perairan dengan golongan oligosaprobik adalah bahan organik dan anorganik dengan konsentrasi yang lebih rendah dari pada bahan pencemar yang mencemari perairan dengan golongan $\beta$-mesosaprobik.

\section{Hubungan Indeks Saprobitas dengan DO, BOD, dan COD}

Hubungan indeks saprobitas dengan kualitas air dapat dilihat pada Tabel 5 dibawah ini:

Tabel 5. Uji Koefisien Determinasi

\begin{tabular}{|c|c|c|c|c|c|c|c|c|c|c|}
\hline \multicolumn{11}{|c|}{ Model Summary $^{\mathbf{b}}$} \\
\hline \multirow{2}{*}{ Model } & \multirow{2}{*}{$\mathrm{R}$} & \multirow{2}{*}{$\begin{array}{c}\mathrm{R} \\
\text { Square }\end{array}$} & \multirow{2}{*}{$\begin{array}{l}\text { Adjusted } \\
\text { R Square }\end{array}$} & \multirow{2}{*}{$\begin{array}{l}\text { Std. } \\
\text { Error of } \\
\text { the } \\
\text { Estimate }\end{array}$} & & \multicolumn{5}{|c|}{ Change Statistics } \\
\hline & & & & & $\begin{array}{l}\text { Durbin- } \\
\text { Watson }\end{array}$ & $\begin{array}{l}\text { R Square } \\
\text { Change }\end{array}$ & $\begin{array}{l}\mathrm{F} \\
\text { Change }\end{array}$ & df1 & df2 & $\begin{array}{l}\text { Sig. } \\
\text { F }\end{array}$ \\
\hline 1 &, $373^{\mathrm{a}}$ &, 139 &,- 184 & ,68755 & 2.311 &, 139 &, 430 & 3 & 8 &, 737 \\
\hline
\end{tabular}

Berdasarkan hasil yang didapatkan variabel DO, BOD, dan COD memiliki hubungan yang cukup kuat dengan saprobitas. Nilai R yang didapatkan yaitu 0,373 yang menunjukkan bahwa hubungan antara variabel DO, BOD, dan COD cukup kuat. Menurut Hidayat et al., (2011), nilai korelasi antara 0-0,25 menunjukkan bahwa korelasi sangat lemah, nilai korelasi 0,25-0,5 menunjukkan korelasi cukup kuat, 0,5-0,75 korelasi kuat, 0,751,00 korelasi sangat kuat, dan nilai korelasi 1 menunjukkan korelasi sempurna. Jika dilihat dari nilai R-Square yang besarnya 0,139 menunjukkan bahwa proposi pengaruh dari ketiga variabel bebas tersebut terhadap saprobitas sebesar 13,9\%. Artinya, variabel DO, BOD, dan COD memiliki pengaruh terhadap saprobitas sebesar 13,9\%. Hal ini menunjukkan adanya hubungan antara sabrobitas dengan ketiga variabe bebas namun hubungannya sangat lemah. Hal ini diperkuat oleh Mirna (2013), interval koefisien korelasi nilai $\mathrm{r}$ antara nilai 0.000- 0.199 menunjukkan tingkat hubungan yang sangat lemah. Nilai saprobitas dapat dipengaruhi oleh faktor lain seperti organisme perairan seperti ikan dan organisme penyusun saprobitas yang hidup pada perairan tersebut. Seperti spesies Euglena viridis yang terdapat pada stasiun 1 dan stasiun 4 sehingga mengakibatkan nilai indeks saprobitas sangat kecil dan tergolong kedalam kategori $\beta$-mesosaprobik.

\section{Kesimpulan}

Kesimpulan yang diperoleh dari penelitian ini adalah sebagai berikut:

Kualitas perairan Waduk Jatibarang, Semarang bulan Mei - Juni termasuk dalam golongan $\beta$ mesosaprobik dan oligosaprobik atau tercemar ringan. Nilai Saprobic Index pada perairan Waduk Jatibarang berkisar antara 0.60-2.75. Nilai TSI pada perairan Waduk Jatibarang berkisar antara 2.02-4.06 yang termasuk dalam golongan oligosaprobik. Nilai kandungan BOD pada perairan Waduk Jatibarang berkisar antara 1.2-2.7 mg/l. Nilai COD pada perairan Waduk Jatibarang berkisar antara 14,91-23,08 mg/l. Nilai Indeks Kualitas Air (IKA) yang didapatkan di Perairan Waduk Jatibarang, Semarang berkisar antara 51.74-55.06 yang tergolong dalam kategori rata-rata atau sedang.

\section{Ucapan Terima Kasih}

Penulis mengucapkan terima kasih kepada Dr. Ir. Suryanti, M.Pi dan Ir. Siti Rudiyanti, M.Si yang telah memberikan arahan, bimbingan, kritik dan saran dalam penulisan artikel ini. Serta semua pihak yang telah memberikan dukungan sehingga penulis dapat menyelesaikan artikel ini. 


\section{Daftar Pustaka}

Basmi J. 2000. Planktonologi: plankton sebagai bioindikator kualitas perairan, Fakultas Perikanan dan Ilmu Kelautan IPB Bogor.

Effendi, H. 2003. Telaah Kualitas Air. Penerbit Kanisius. Yogyakarta

Ferdian, F., I. Maulina, Roshidah. 2012. Analisis Permintaan Ikan Lele Dumbo (Clarias gariepinus) Konsumsi di Kecamatan Losarang Kabupaten Indramayu. Jurnal Perikanan dan Kelautan., 3(4):93-98

Happy, R. A., Masyamsir, Y. Dhahiyat. 2012. Distribusi Kandungan Logam Pb dan Cd pada Kolom Air dan Sedimen Daerah Aliran Sungai Citarum Hulu. Jurnal Perikanan dan Kelautan., 3(3):175-182

Hariyati, L., A. F. Syah, dan H. Triajie. 2010. Studi Komunitas Fitoplankton di Pesisir Kenjeran Surabaya sebagai Bioindikator Kualitas Perairan. Jurnal Kelautan., 3(2):117-131

Hidayat, T., N. Istiadah. 2011. Panduan Lengkap Menguasai SPSS 19 untuk Mengolah Data Statistik Penelitian. Jakarta: Mediakita

Kasrina, S. Irawati, W. E. Jayanti. 2012. Ragam Jenis Mikroalga di Air Rawa Kelurahan Bentiring Permai Kota Bengkulu sebagai Alternatif Sumber Belajar Biologi SMA. Jurnal Exacta. 1(10):36-44

Mirna. 2013. Performance of Ship Asistance Program for Fisheries. Jurnal Ekonomi Pembangunan., 14(2):180191

OdumE. P. 1971. Fundamental of ecology. Third Ed. W.B. Sounders Company. Philadelphia. 574.

Persone G and De Pauw N. 1979. System of biological indicator for water quality assessment, In: Commission of European Community. 1979. Biological aspects of freshwater pollution. Pergamon Press. New York . 39-75.

Pirzan A. R., P. R. Pong-Masak. 2008. Hubungan Keragaman Fitoplankton dengan Kualitas Air di Pulau Baulung, Kabupaten Takalar, Sulawesi Selatan. Biodiversitas. 3(9):217-221

Republik Indonesia. 2001. Peraturan Pemerintah No. 82 Tahun 2001 tentang Pengelolaan Kualitas Air dan Pengendalian Pencemaran Air

Sachlan. 1982. Planktonologi. Fakultas Peternakan. Universitas Diponegoro, Semarang

Sumargono, A. 2006. Kesesuaian Pemanfaatan Waduk Cacaban dalam Pengembangan Wisata Alam di Kabupaten Tegal.

Syamiazi, F. D. N., Saifullah, F. R. Indrayatno. 2015. Kondisi Air di Waduk Nadra Kerenceng Kota Cilegon Provinsi Banten. Jurnal Akuatik., 6(2):161-169

Tyagi S., S. Bhavtosh, S. Prashant, D. Rajendra. 2013. Water Quality Assesment in Terms of Water Quality Index. American Journal of Water Resources, 1(3):34-38

Wartiniyati, S. Anggoro, B. Hendrarto, H. R. Sunoko. 2016. The Rainy Leachate and Saprobic Category Impact Distribution Index to Reach Furthest [Wolinsky 2005] and Plankton Diversity in Landfill SBBL. Journal of Applied Environmental and Biological Sciences., 6(10):1-9 